\title{
Front Matter: Volume 8306
}

, "Front Matter: Volume 8306," Proc. SPIE 8306, Photonics, Devices, and Systems V, 830601 (4 November 2011); doi: 10.1117/12.918136

SPIE. Event: Photonics Prague 2011, 2011, Prague, Czech Republic 


\title{
PROCEEDINGS OF SPIE
}

\section{Photonics, Devices, and Systems V}

\author{
Pavel Tománek \\ Dagmar Senderáková \\ Petr Páta \\ Editors
}

24-26 August 2011

Prague, Czech Republic

Cosponsored by

EOS-European Optical Society

Organized by

CSSF-Czech and Slovak Society for Photonics

Action M Agency (Czech Republic)

Cooperating Organizations

SPIE

Published by

SPIE 
The papers included in this volume were part of the technical conference cited on the cover and title page. Papers were selected and subject to review by the editors and conference program committee. Some conference presentations may not be available for publication. The papers published in these proceedings reflect the work and thoughts of the authors and are published herein as submitted. The publisher is not responsible for the validity of the information or for any outcomes resulting from reliance thereon.

Please use the following format to cite material from this book:

Author(s), "Title of Paper," in Photonics, Devices, and Systems V, edited by Pavel Tománek, Dagmar Senderáková, Petr Páta, Proceedings of SPIE Vol. 8306 (SPIE, Bellingham, WA, 2011) Article CID Number.

ISSN 0277-786X

ISBN 9780819489531

Published by

SPIE

P.O. Box 10, Bellingham, Washington 98227-0010 USA

Telephone +1 3606763290 (Pacific Time) · Fax +1 3606471445

SPIE.org

Copyright (C) 2011, Society of Photo-Optical Instrumentation Engineers

Copying of material in this book for internal or personal use, or for the internal or personal use of specific clients, beyond the fair use provisions granted by the U.S. Copyright Law is authorized by SPIE subject to payment of copying fees. The Transactional Reporting Service base fee for this volume is $\$ 18.00$ per article (or portion thereof), which should be paid directly to the Copyright Clearance Center (CCC), 222 Rosewood Drive, Danvers, MA 01923. Payment may also be made electronically through CCC Online at copyright.com. Other copying for republication, resale, advertising or promotion, or any form of systematic or multiple reproduction of any material in this book is prohibited except with permission in writing from the publisher. The CCC fee code is 0277-786X/11/ \$18.00.

Printed in the United States of America.

Publication of record for individual papers is online in the SPIE Digital Library.

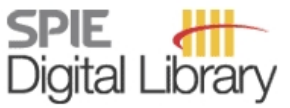

SPIEDigitalLibrary.org

Paper Numbering: Proceedings of SPIE follow an e-First publication model, with papers published first online and then in print and on CD-ROM. Papers are published as they are submitted and meet publication criteria. A unique, consistent, permanent citation identifier (CID) number is assigned to each article at the time of the first publication. Utilization of CIDs allows articles to be fully citable as soon as they are published online, and connects the same identifier to all online, print, and electronic versions of the publication. SPIE uses a six-digit CID article numbering system in which:

- The first four digits correspond to the SPIE volume number.

- The last two digits indicate publication order within the volume using a Base 36 numbering system employing both numerals and letters. These two-number sets start with $00,01,02,03,04$, $05,06,07,08,09,0 A, 0 B \ldots 0 Z$, followed by 10-1Z, 20-2Z, etc.

The CID number appears on each page of the manuscript. The complete citation is used on the first page, and an abbreviated version on subsequent pages. Numbers in the index correspond to the last two digits of the six-digit CID number. 


\section{Contents}

$\begin{aligned} x \mathrm{x} & \text { Conference Committees } \\ \text { xiii } & \text { Introduction } \\ \text { xv } & \text { Welcome Address } \\ \text { xvii } & \text { Conference Photos } \\ \text { xxvii } & \text { SPIE Best Student Award } \\ \text { xxix } & \text { CSSF Young Scientist Award } \\ \text { xxxi } & \text { Conference Supporters }\end{aligned}$

\section{PLENARY PRESENTATIONS}

830602 Towards green high capacity optical networks (Plenary Paper) [8306-65]

I. Glesk, M. N. Mohd Warip, S. K. Idris, T. B. Osadola, I. Andonovic, Univ. of Strathclyde (United Kingdom)

830603 The physics in applications of ultrafast lasers (Plenary Paper) [8306-17]

D. Wortmann, M. Reininghaus, J. Finger, RWTH Aachen Univ. (Germany); C. Dold, Inspire AG (Switzerland); P. Russbueldt, Fraunhofer Institute for Laser Technology (Germany);

R. Poprawe, RWTH Aachen Univ. (Germany) and Fraunhofer Institute for Laser Technology (Germany)

830604 Light: the physics of the photon (Plenary Paper) [8306-20]

O. Keller, Aalborg Univ. (Denmark)

\section{LASERS AND PHOTODETECTORS IN INDUSTRY, IMAGING, AND SENSORS}

830605 Preparation of spherical optical microresonators and their resonance spectra in air and gaseous acetone [8306-10]

V. Matéjec, F. Todorov, Institute of Photonics and Electronics (Czech Republic); M. Jelinek, M. Fibrich, Czech Technical Univ. in Prague (Czech Republic); M. Chomát, Institute of Photonics and Electronics (Czech Republic); V. Kubeček, Czech Technical Univ. in Prague (Czech Republic); I. Barton, T. Martan, D. Berková, Institute of Photonics and Electronics (Czech Republic)

830606 A discussion of sources of error in laser-speckle based systems [8306-42]

B. G. Zagar, J. Lettner, Johannes Kepler Univ. Linz (Austria)

830607 Position measurement in standing wave interferometer for metrology of length [8306-60]

J. Lazar, O. Číp, J. Oulehla, P. Pokorný, Institute of Scientific Instruments (Czech Republic);

A. Fejfar, J. Stuchlík, Institute of Physics (Czech Republic) 
830608 Preparation and characterization of highly thulium- and alumina-doped optical fibers for single-frequency fiber lasers [8306-55]

P. Honzatko, A. Dhar, I. Kasik, O. Podrazky, V. Matejec, P. Peterka, Institute of Photonics and Electronics (Czech Republic); W. Blanc, B. Dussardier, Lab. de Physique de la Matiere Condensee, CNRS, Univ. de Nice-Sophia Antipolis (France)

830609 Optical loop memory based on controlling the lasing of optical fiber loop amplifiers using a wavelength-tunable add/drop filter [8306-02]

Y. Maeda, H. Tanimoto, Kinki Univ. (Japan); H. Nakayama, Hikari-triode Co., Ltd. (Japan)

8306 OA Measurement of vibrations at different sections of rail through fiber optic sensors [8306-38]

A. Barreda, T. Molina-Jiménez, E. Valero, S. Recuero, AIDO: Nicolás Copérnico (Spain)

8306 OB Silicon micro sensors as integrated readout platform for colorimetric and fluorescence based opto-chemical transducers [8306-58]

M. Will, CiS-Institute for Micro Sensors GmbH (Germany); T. Martan, Institute of Photonics and Electronics (Czech Republic); O. Brodersen, CiS-Institute for Micro Sensors GmbH (Germany)

8306 0C Deformation measurement along two directions of a continuously deforming object by using two lasers and one color camera [8306-27]

T. Senzawa, M. Adachi, Kanazawa Univ. (Japan)

8306 OD Performance evaluation of fast, high precision laser rangefinder electronics with a pulsed laser [8306-40]

D. Vyhlídal, M. Jelínek, M. Čech, V. Kubeček, Czech Technical Univ. (Czech Republic)

8306 OE Light source for low-coherence interferometry combining LED and single mode optical fiber [8306-56]

Z. Buchta, B. Mikel, Š. Řeřucha, J. Lazar, O. Číp, Institute of Scientific Instruments (Czech Republic)

8306 OF Stabilization of DFB laser diodes with 760nm and $1541 \mathrm{~nm}$ wavelength [8306-57]

B. Mikel, Z. Buchta, J. Lazar, M. Cizek, O. Cip, Institute of Scientific Instruments (Czech Republic)

8306 OG Diamond Raman laser in eye safe region [8306-12]

H. Jelínková, O. Kitzler, M. Jelínek, J. Šulc, M. Němec, V. Kubeček, Czech Technical Univ. in Prague (Czech Republic)

\section{BIOPHOTONICS}

$8306 \mathrm{OH} \quad$ Laser evaporation of models of normal and tumoral biological tissues [8306-05] V. A. Ul'yanov, A. K. Dmitriev, A. N. Konovalov, V. N. Kortunov, Institute on Laser and Information Technologies (Russian Federation); I. V. Reshetov, O. V. Matorin, P.A. Hertzen Cancer Research Institute (Russian Federation)

8306 Ol Metamaterial resonator arrays for organic and inorganic compound sensing [8306-32] L. La Spada, F. Bilotti, L. Vegni, Roma Tre Univ. (Italy) 
8306 0J Detecting positive surgical margins of prostate tissues using elastic light single-scattering spectroscopy [8306-67]

M. Canpolat, T. Denkçeken, I. Başsorgun, S. Yücel, M. A. Çiftçioğlu, M. Baykara, Akdeniz Üniv. (Turkey)

8306 OK Photosensitizer fluorescence emission during photodynamic therapy applied to dermatological diseases [8306-25]

I. Salas-García, F. Fanjul-Vélez, N. Ortega-Quijano, J. L. Arce-Diego, Univ. of Cantabria (Spain)

8306 OL Raman microspectroscopy of algal lipid bodies: $\beta$-carotene as a volume sensor [8306-31] Z. Pilát, S. Bernatová, J. Ježek, M. Šery, O. Samek, P. Zemánek, Institute of Scientific Instruments (Czech Republic); L. Nedbal, Global Change Research Ctr. (Czech Republic); M. Trtílek, Photon Systems Instruments (Czech Republic)

$83060 \mathrm{M}$ Accommodation and vergence infrared measurement using hologram stimulus [8306-66] T. Jindra, J. Dušek, Charles Univ. in Prague (Czech Republic); M. Dostálek, Paediatric Ophtalmology Ctr., BINOCULAR s.r.o. (Czech Republic); P. Fiala, M. Škereň, Czech Technical Univ. in Prague (Czech Republic)

$8306 \mathrm{ON}$ THz spectroscopy and molecular modeling of bovine serum albumin under various hydration conditions [8306-50]

M. Mernea, O. Calborean, L. Petrescu, D. Zatreanu, Univ. of Bucharest (Romania); O. Sandu, T. Dascalu, National Institute for Laser, Plasma and Radiation Physics (Romania);

D. F. Mihailescu, Univ. of Bucharest (Romania)

830600 Polarization of scattered light in biological tissue [8306-03]

H. M. Abubaker, P. Tománek, Brno Univ. of Technology (Czech Republic)

\section{DESIGN AND SIMULATION OF PHOTONIC DEVICES}

8306 OP The cavity resonator design: stochastic optimization of the transmission line method [8306-29]

S. Jurečka, J. Müllerová, M. Dado, Univ. of Žilina (Slovakia)

$83060 Q$ Preparation and characterization of bottle optical microresonators with circular and hexagonal cross-sections [8306-22]

F. Todorov, J. Čtyroký, V. Matějec, M. Chomát, D. Berková, I. Kašík, T. Martan, Institute of Photonics and Electronics (Czech Republic); V. Kubeček, M. Jelínek, M. Fibrich, Czech Technical Univ. in Prague (Czech Republic)

8306 OR Light polarization state analyzer based on two spatial carrier frequencies method [8306-15] S. Drobczyński, W. A. Woźniak, P. Kurzynowski, Wrocław Univ. of Technology (Poland)

8306 OS Application of infrared ATR ellipsometry for measurement of solid samples: calibration procedure [8306-63] Z. Mrázková, D. Hrabovský, K. Postava, J. Pištora, Technical Univ. of Ostrava (Czech Republic)

8306 OT WDM hybrid microoptical transceiver with Bragg volume grating [8306-16] V. Jeřábek, J. Armas, D. Mareš, V. Prajzler, Czech Technical Univ. in Prague (Czech Republic) 
8306 OU Multimode fiber-based transmitter for free space optical communications [8306-26] F. Fanjul-Vélez, Univ. of Cantabria (Spain); O. Wilfert, Brno Univ. of Technology (Czech Republic); M. Hampl, Honeywell, Ltd. (Czech Republic); I. Salas-García, N. Ortega-Quijano, J. L. Arce-Diego, Univ. of Cantabria (Spain)

\section{DIFFRACTIVE PHOTONIC DEVICES}

8306 OV Synthesis of diffractive structures (Invited Paper) [8306-43]

L. Kotačka, P. Vízdal, T. Bĕhounek, Optaglio s.r.o. (Czech Republic)

8306 OW Optoelectronic systems with delayed acousto-optic feedback [8306-07]

V. I. Balakshy, Y. I. Kuznetsov, Moscow State Univ. (Russian Federation)

8306 0X Designing of binary diffractive optical elements for beams performing [8306-36]

L. Cozzella, C. Simonetti, D. Papalillo, G. Schirripa Spagnolo, Univ. degli Studi di Roma Tre (Italy)

\section{GUIDED WAVE PHOTONICS}

8306 OY Comparison of 2D and 3D Fourier modal methods for modeling subwavelength-structured silicon waveguides (Invited Paper) [8306-61]

P. Kwiecien, I. Richter, Czech Technical Univ. in Prague (Czech Republic); J. Čtyroký, Institute of Photonics and Electronics (Czech Republic)

$83060 Z$ Broadband dispersion compensating photonic crystal fiber [8306-09] M. Lucki, R. Zeleny, Czech Technical Univ. in Prague (Czech Republic)

830610 Dynamical properties of a coupled nonlinear dielectric waveguide-surface-plasmon system as another type of Josephson junction [8306-28]

Y. Ekşioğlu, Ö. E. Müstecaplıoğlu, K. Güven, Koç Univ. (Turkey)

830611 Study of thin films of $\mathrm{LiNbO}_{3}$ using FTIR and Raman spectroscopy [8306-08] M. Zezulová, Czech Technical Univ. in Prague (Czech Republic); M. Jelínek, Czech Technical Univ. in Prague (Czech Republic) and Institute of Physics (Czech Republic); V. Železný, T. Kocourek, Institute of Physics (Czech Republic)

830612 Modeling of a fiber-optic sensor based on surface plasmon resonance including the dispersion of the analyte [8306-34]

D. Ciprian, P. Hlubina, Technical Univ. Ostrava (Czech Republic)

\section{ORGANIC PHOTONIC MATERIALS AND DEVICES}

830613 High performance low refractive index materials for photonics I: preliminary characterization [8306-21]

A. B. Wojcik, Wrocław Research Ctr. ElT+ Ltd. (Poland) and Hybrid Glass Technologies (United States); Ł. John, S. Szafert, Wrocław Research Ctr. ElT+ Ltd. (Poland) and Univ. of Wrocław (Poland) 
830614 Investigation of nonlinear chalcogenide fiber Bragg gratings as a promising tool for alloptical switching [8306-64]

E. Jurisová, J. Müllerová, M. Koščová, Univ. of Žilina (Slovakia)

830615 Novel ene-yne compounds as quadratic nonlinear optical materials [8306-49]

D. Lumpi, E. Horkel, B. Stoeger, C. Hametner, F. Kubel, G. A. Reider, J. Froehlich, Vienna Univ. of Technology (Austria)

NON-LINEAR MATERIALS, DEVICES, AND APPLICATIONS

830616 Dual pulse operation of $1.5 \mu \mathrm{m}$ picosecond intracavity synchronously pumped optical parametric oscillator [8306-44]

A. Zavadilová, V. Kubeček, Czech Technical Univ. in Prague (Czech Republic); J.-C. Diels, Univ. of New Mexico (United States); J. Šulc, Czech Technical Univ. in Prague (Czech Republic)

830617 Peculiarities of As-S glass structure doped with ytterbium [8306-59]

A. P. Paiuk, A. V. Stronski, V. Lashkaryov Institute of Semiconductor Physics (Ukraine); M. Vlček, Univ. of Pardubice (Czech Republic); A. A. Gubanova, T. A. Krys'kov, Kamianets-Podilsky National Univ. (Ukraine); P. F. Oleksenko, V. Lashkaryov Institute of Semiconductor Physics (Ukraine)

830618 Influence of deposition conditions of ZnO thin films on their photonic properties [8306-51] M. Netrvalová, L. Prušáková, P. Novák, P. Šutta, Univ. of West Bohemia (Czech Republic)

830619 Local laser-induced crystallization of lanthanum boron germanate glass near $\mathrm{LaBGeO}_{5}$ composition [8306-33]

S. V. Lotarev, T. O. Gelmanova, D. Mendeleyev Univ. of Chemical Technology of Russia (Russian Federation); Y. S. Priseko, Research and Production Enterprise VELIT (Russian Federation); A. Paleari, D. Mendeleyev Univ. of Chemical Technology of Russia (Russian Federation) and CNISM, Univ. of Milano-Bicocca (Italy); V. N. Sigaev, D. Mendeleyev Univ. of Chemical Technology of Russia (Russian Federation)

8306 1A Photosensitive polyurethanes for optical record [8306-11]

A. Gerbreders, Univ. of Latvia (Latvia) and Daugavpils Univ. (Latvia); J. Aleksejeva, J. Teteris, Univ. of Latvia (Latvia)

\section{NANOPHOTONICS + NANOOPTICS}

8306 IB All-optical multi-dimensional imaging of energy-materials beyond the diffraction limit (Invited Paper) [8306-30]

S. Smith, D. J. Dagel, L. Zhong, P. Kolla, South Dakota School of Mines and Technology (United States); S.-Y. Ding, National Renewable Energy Lab. (United States)

8306 1C Partial polarization of pulsed light beams [8306-54]

T. Voipio, T. Setälä, Aalto Univ. (Finland); A. T. Friberg, Aalto Univ. (Finland), Univ. of Eastern Finland (Finland), and Royal Institute of Technology (KTH) (Sweden) 
8306 1D Advanced optical manipulation with tailored counter-propagating laser beams [8306-23] O. Brzobohatý, Institute of Scientific Instruments (Czech Republic); T. Čižmár, Univ. of St. Andrews (United Kingdom); V. Karásek, P. Zemánek, Institute of Scientific Instruments (Czech Republic)

8306 IE Theoretical study of photon emission related to evanescent fields [8306-19]

D. S. Olesen, O. Keller, Aalborg Univ. (Denmark)

$8306 \mathrm{lF}$ Magneto-optical effects in nanostructures with reduced symmetry [8306-46] T. Fördös, K. Postava, J. Pištora, Technical Univ. of Ostrava (Czech Republic)

8306 IG Synthesis of $\mathrm{ZnO}$ nanostructures with different morphologies by a direct melt oxidation of Al-Zn mixture [8306-24]

G.-H. Lee, Dong-Eui Univ. (Korea, Republic of)

SOLID STATE LIGHTING + LED, LD, OLED, SOLAR CELLS

$8306 \mathrm{1H} \quad$ Local measurement of solar cell emission characteristics [8306-35]

P. Škarvada, P. Tománek, L. Grmela, Brno Univ. of Technology (Czech Republic)

830611 Investigation of the photon emission from $p-n$ junction of silicon solar cells studied by electro-optical methods [8306-18]

R. Macku, P. Koktavy, P. Tomanek, Brno Univ. of Technology (Czech Republic)

8306 1J Studies of active Nd-doped silicon rich silicon oxide waveguides [8306-13]

P. Pirasteh, J. Charrier, Y. Dumeige, CNRS FOTON, Univ. de Rennes 1 (France); J.-L. Doualan, P. Camy, O. Debieu, CIMAP, CNRS/CEA/ENSICAEN/UCBN (France); Y. G. Boucher, CNRS FOTON, Univ. de Rennes 1 (France); F. Gourbilleau, CIMAP, CNRS/CEA/ENSICAEN/UCBN (France)

$83061 \mathrm{~K}$ Investigation of optical properties of $\mathrm{SiC} /(\mathrm{SiC}) 1-x(\mathrm{AIN}) \times$ heterostructures [8306-52] G. Safaraliev, B. Bilalov, Dagestan State Technical Univ. (Russian Federation); D. Dallaeva, Dagestan State Technical Univ. (Russian Federation) and Brno Univ. of Technology (Czech Republic); S. Ramasanov, K. Geraev, Dagestan State Technical Univ. (Russian Federation); P. Tománek, Brno Univ. of Technology (Czech Republic)

$8306 \mathrm{lL}$ Photoluminescent properties of rare-earth ions in $\mathrm{TeO}_{2}-\mathrm{WO}_{3}-\mathrm{PbO}_{-} \mathrm{La}_{2} \mathrm{O}_{3}$ glasses [8306-14] Z. Mazurak, Ctr. of Polymer and Carbon Materials (Poland); B. Burtan, J. Cisowski, Cracow Univ. of Technology (Poland); M. Czaja, Silesian Univ. (Poland); R. Lisiecki,

W. Ryba-Romanowski, Institute of Low Temperature and Structure Research (Poland); M. Reben, J. Wasylak, AGH Univ. of Science and Technology (Poland)

8306 1M Photoluminescence properties of polynaphthalisoimides and polynapththalimides in solutions and thin layers [8306-48]

A. Wanic, Z. Mazurak, Ctr. of Polymer and Carbon Materials (Poland); J. Cisowski, Cracow Univ. of Technology (Poland)

8306 IN LED applications in road and railway signals: is it possible to fit specifications? [8306-45] D. Papalillo, P. Del Vecchio, G. Schirripa Spagnolo, Univ. degli Studi di Roma Tre (Italy) 
PHOTONICS: EDUCATION AND MULTIMEDIA

$830610 \quad$ Holographic grating: a useful tool [8306-37]

D. Senderakova, M. Drzik, A. Strba, V. Mesaros, Comenius Univ. (Slovakia)

8306 IP CCD noise influence on JPEG2000 compression of astronomical images [8306-39]

P. Páta, Czech Technical Univ. in Prague (Czech Republic)

8306 1Q Wavelet transform for processing of video from MAIA system [8306-41]

E. Anisimova, P. Páta, M. Blazek, K. Fliegel, S. Vitek, Czech Technical Univ. in Prague (Czech Republic); P. Koten, Astronomical Institute (Czech Republic)

Author Index 
Downloaded From: https://www.spiedigitallibrary.org/conference-proceedings-of-spie on 26 Apr 2023

Terms of Use: https://www.spiedigitallibrary.org/terms-of-use 


\title{
Conference Committees
}

\author{
Conference Chairs
}

Pavel Tománek, Brno University of Technology (Czech Republic) Dagmar Senderáková, Comenius University (Slovakia)

Petr Páta, Czech Technical University in Prague (Czech Republic)

Program Committee

Oleg Angelsky, Chernivtsi University (Ukraine)

José Luis Arce-Diego, Universidad de Cantabria (Spain)

Mario Bertolotti, Università di Roma I (Italy)

Pavel Cheben, Institute for Microstructural Sciences (Canada)

Jiří Čtyroký, Institute of Photonics and Electronics (Czech

Republic)

Ivan Glesk, Strathclyde University (United Kingdom)

Helena Jelínková, Czech Technical University (Czech Republic)

Ivan B. Kovsh, LAS Moscow (Russia)

Roberto Morandotti, INRS-EMT (Canada)

Petr Páta, Czech Technical University (Czech Republic)

Jürgen Popp, Friedrich-Schiller-Universität Jena (Germany)

Reinhart Poprawe, Fraunhofer Institute for Laser Technology

(Germany)

Dagmar Senderáková, Comenius University (Slovakia) and

SPIE (United States)

Steve J. Smith, South Dakota School of Mines and Technology (United States)

Pavel Tománek, Brno University of Technology (Czech Republic)

Pavel Zemánek, Institute of Scientific Instruments (Czech

Republic)

Xing Zhu, Beijing University (China)

Organizing Committee

Pavel Tománek, SPIE (United States) and EOS-European

Optical Society (Germany)

Miroslav Jedlička, CSSF-Czech and Slovak Society for

Photonics (Czech Republic)

Petr Páta, Czech Technical University in Prague (Czech

Republic)

Dagmar Senderáková, SPIE (United States)

Milena Zeithamlová, Action M Agency (Czech Republic) 
Session Chairs

Plenary Sessions

Miroslav Jedlička, CSSF-Czech and Slovak Society for Photonics (Czech Republic)

Helena Jelínková, CSSF-Czech and Slovak Society for Photonics (Czech Republic)

Topics

1 Lasers and Photodetectors in Industry, Imaging, and Sensors Reinhart Poprawe, Fraunhofer Institute for Laser Technology (Germany)

Josef Lazar, Institute of Scientific Instruments, AS CR (Czech Republic)

2 Biophotonics

Jürgen Popp, Friedrich-Schiller-Universität Jena (Germany)

Volker Dekert, Friedrich-Schiller-Universität Jena (Germany)

3 Design and Simulation of Photonic Devices

Ivan Glesk, University of Strathclyde (United Kingdom)

$4 \quad$ Photonic Crystals and Photonic Bandgap Structures

Václav Kubeček, Czech Technical University in Prague (Czech Republic)

5 Diffractive Photonic Devices

Dagmar Senderáková, Comenius University (Slovakia)

$6 \quad$ Guided Wave Photonics

Alper Kiraz, Koç University (Turkey)

$7 \quad$ Organic Photonic Materials and Devices

Vlastimil Matějec, Institute of Photonics and Electronics (Czech Republic)

$8 \quad$ Non-Linear Materials, Devices, and Applications

Jiří Čtyroký, Institute of Photonics and Electronics (Czech Republic)

$9 \quad$ Nanophotonics and Nanooptics

Pavel Tománek, Brno University of Technology (Czech Republic)

10 Solid State Lighting + LED, LD, OLED, Solar Cells

Steve J. Smith, South Dakota School of Mines and Technology (United States)

11 Photonics: Education and Multimedia

Håkan Pettersson, Halmstad University (Sweden) and Lund University (Sweden) 


\section{Introduction}

This volume contains 61 peer-reviewed submissions selected from 97 contributions presented during the seventh Photonics Prague 2011 conference. The conference is dedicated to the development of photonics, particularly in the eastern European countries, with emphasis on systems and devices in photonics.

The conference included 11 topical sessions covering various aspects of photonics:

1. Lasers and Photodetectors in Industry, Imaging, and Sensors

2. Biophotonics

3. Design and Simulation of Photonic Devices

4. Photonic Crystals and Photonic Bandgap Structures

5. Diffractive Photonic Devices

6. Guided Wave Photonics

7. Organic Photonic Materials and Devices

8. Non-Linear Materials, Devices, and Applications

9. Nanophotonics and Nanooptics

10. Solid State Lighting + LED, LD, OLED, Solar Cells

11. Photonics: Education and Multimedia

The conference attracted 102 participants from 24 countries, and the presence of many young first-time participants was greatly appreciated (one third were local from the Czech Republic and Slovakia). The scientific program was comprised of 4 plenary talks, 7 invited talks, 41 oral presentations, and 45 poster presentations.

Also, this volume contains papers written by SPIE Student Best Paper Award winners, Timo Voipio (FIN), Zdeněk Pilát (CZE), Irene Salas-Garcia (ESP), and Dann S. Olesen (DEN), as well as of CSSF Young Scientist Award winners, Oto Brzobohatý (CZE) and Markéta Zezulová (CZE).

We would like to thank the authors for their excellent contributions which made for an outstanding high-level conference, and members of the Program Committee for their fine effort in preparing the conference technical program, as well as for their opinion concerning the submitted papers. Last but not least, we would like to thank the SPIE staff for their support in preparing these Proceedings.

We expect the Photonics Prague series to continue and we look forward to inviting scientists from all countries to attend next Photonics Prague conference in 2014.

\section{Pavel Tománek Dagmar Senderáková Petr Páta}


Downloaded From: https://www.spiedigitallibrary.org/conference-proceedings-of-spie on 26 Apr 2023

Terms of Use: https://www.spiedigitallibrary.org/terms-of-use 


\section{Welcome Address}

Prague

August 24, 2011

Ladies and gentlemen, dear participants, dear colleagues,

We welcome you who are coming from countries all over the world to the Seventh International Conference Photonics Prague 2011 (Photonics, Devices, and System V) held 24-26 August 2011 at the Artemis Olympik Hotel Congress Centre in Prague, Czech Republic.

The conference traditionally represents the most important event organized by the Czech and Slovak Society for Photonics every three years. This year, it is organized under the auspice of the Lord Mayor of Prague, and is sponsored by the European Optical Society. We thank all of them for their support.

Photonics is driving innovation in Europe and one of the most important key technologies for markets in the $21^{\text {st }}$ century. Photonics is cross-sectoral technology, which comprises ten sectors in Europe and more than 40 major product segments. Its diverse applications play a vital role in the information society.

Today, lighting, measurement and automated vision, production technology, medical technology and life science, defense photonics, and optical components and systems share more than $10 \%$ of the total European production volume, while optical communications, solar energy, information technology, and flat panel displays cover share less than $10 \%$.

European photonics production is now comparable to that of microelectronics in Europe and it is expected to exceed it soon. To reach this result, it is necessary to ensure and strengthen a close cooperation between academia, the research community, and industry. The foremost idea of the organizers was to show the variety of photonic approaches to the current development of the high technology in Europe and worldwide in areas such as information and communication, lighting, manufacturing, security or life science, and health. Furthermore, this year the trend is very important in view of the $8^{\text {th }}$ Framework Programme of European Commission and of further international collaboration.

Therefore a principal task of the photonics conference series in Prague is to create an environment for open exchange of topical research information and to stimulate a discussion of novel concepts and fields of application. This 
conference series also represents the important regional forum for advances in nature of physical phenomena used in photonics, instruments and devices development, and a wide range of industrial photonics applications.

The conference program committee has suggested four plenary talks showing the emerging trends in photonics, not only from experimental or technical points of view, but also from its theoretical principles. In the first part, Ivan Glesk gives a talk, Toward green high capacity optical network, and Reinhart Poprawe gives a talk. The physics in applications of ultrafast lasers. In the second part, Ole Keller gives a talk, Light: the physics of the photon, and Jürgen Popp gives a talk, Modern biophotonics: a key enabling technology for biomedical diagnostics.

From the numerous abstracts that have been submitted, eight were selected as invited, 47 for oral presentation, and 45 for poster presentation, which will be presented during the three day meeting. The presentations are thematically distributed over 11 topics.

About 110 scientists from 24 countries are attending the conference. A quick glance at the program shows that most participants are local (Czech and Slovak) or from eastern European countries. A more detailed look reveals the current trends in the research field.

We acknowledge all the contributors for submitting the manuscripts in time and for preparing their oral or poster presentations.

We would like to thank the International Program Committee for their help in the selection of papers and the review procedures, and especially the members of the local organizing committee for their efforts in preparing this conference.

We hope that you will profit not only from the conference technical program and its social events, but also from the beauties of the wonderful city of Prague.

We wish you all an inspiring meeting and we hope you will enjoy it.

Dr. Miroslav Jedlička

President of Czech and Slovak Society for Photonics

Prof. Dr. Pavel Tománek Conference Chair 


\section{Conference Photos}

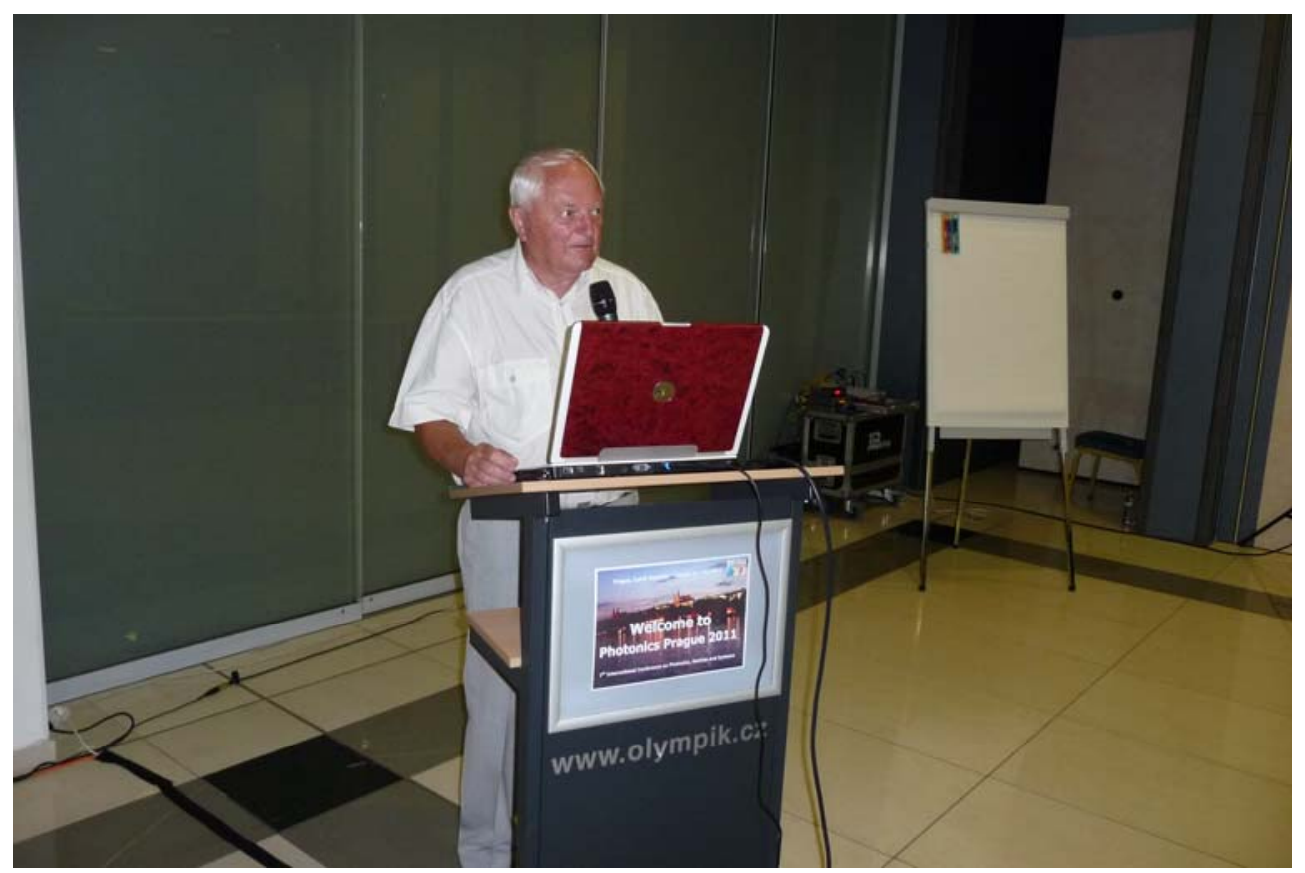

Miroslav Jedlička (President of Czech and Slovak Society for Photonics) is presenting a welcome address,

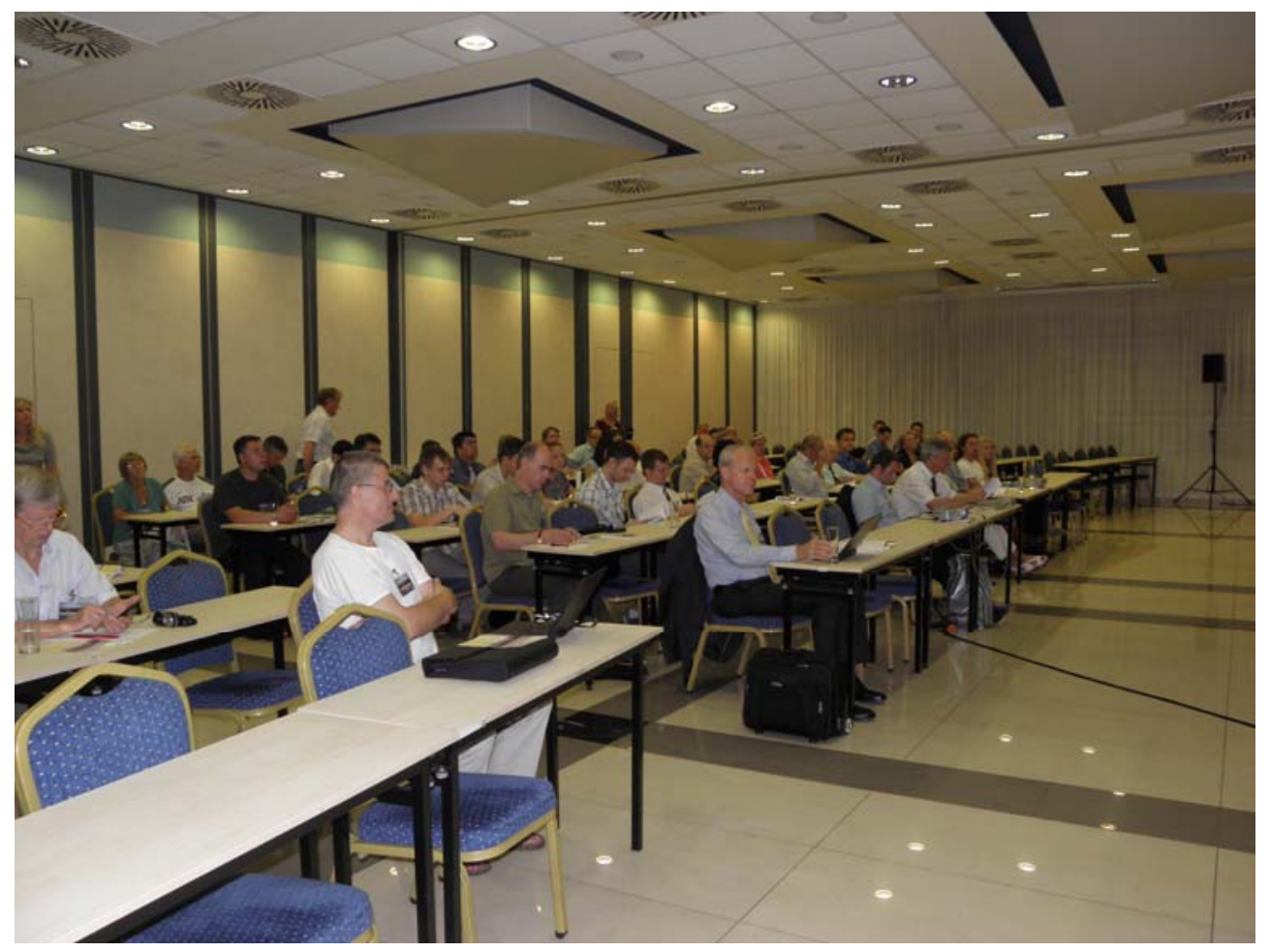

and the auditory is listening his message. 


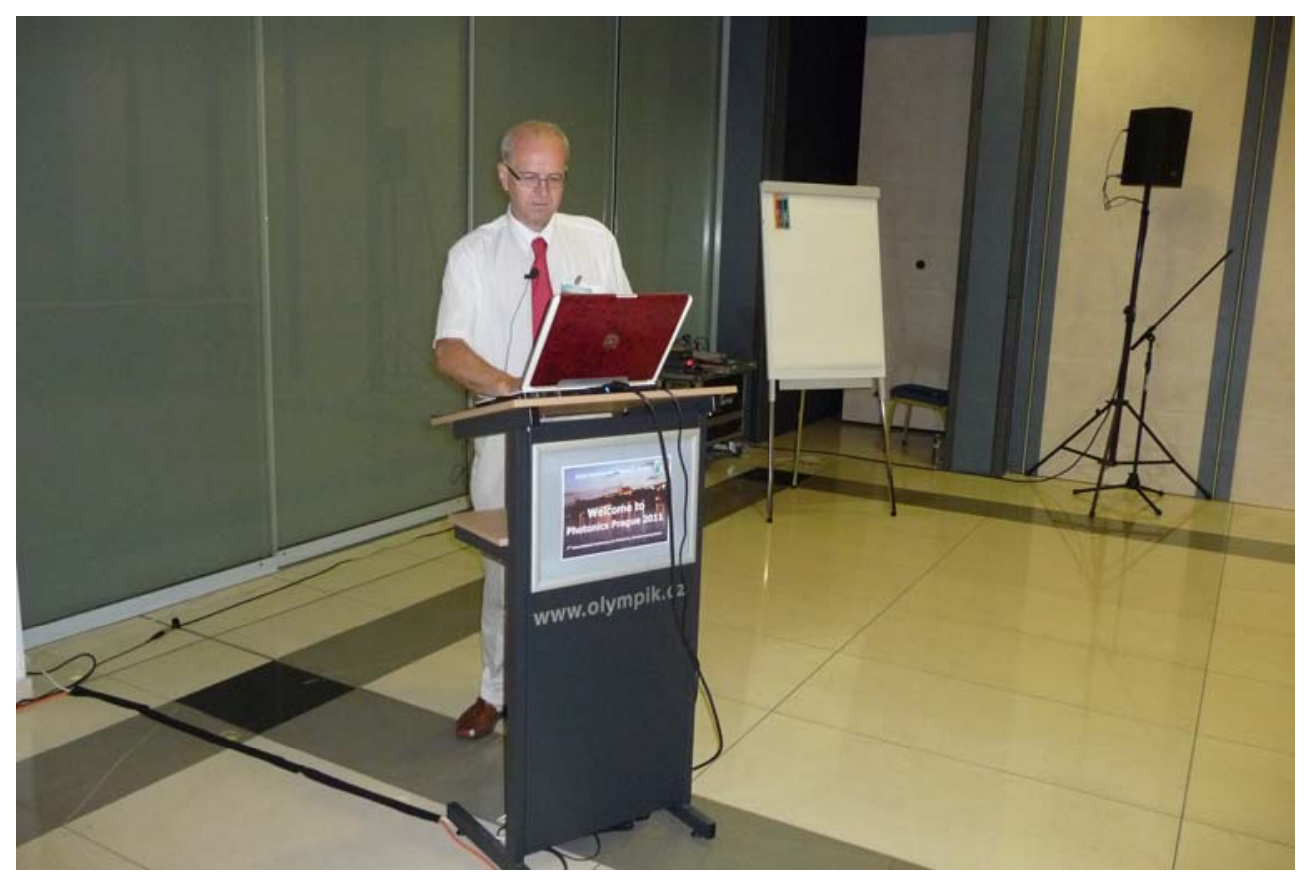

Ivan Glesk (Strathclyde University, United Kingdom) presents WKH-first plenary talk $\square$ Towards green high capacity optical network.

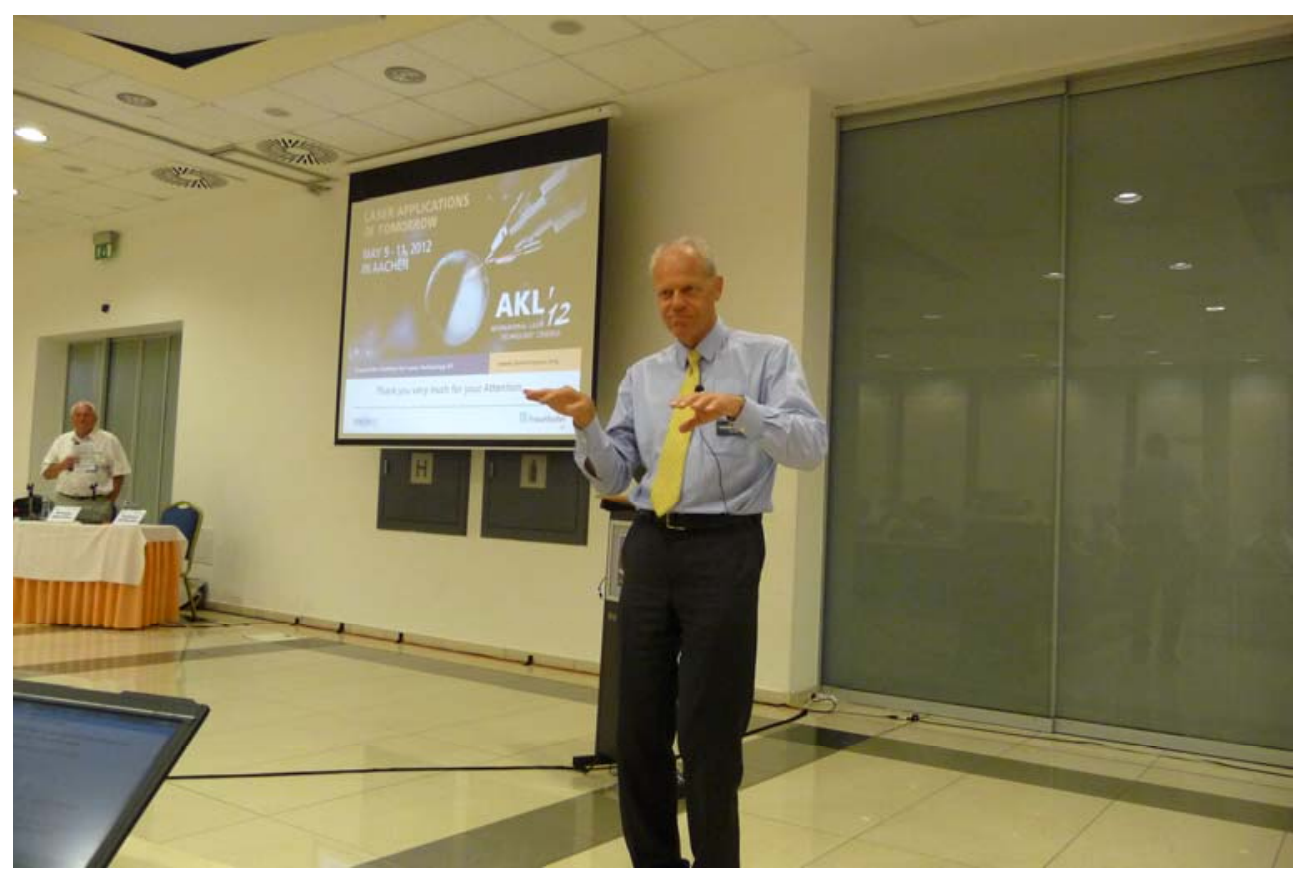

Reinhart Poprawe (Fraunhofer Institute for Laser Technology, Aachen, Germany) explaining in the second plenary talkWThe physics in applications of ultrafast lasers. 


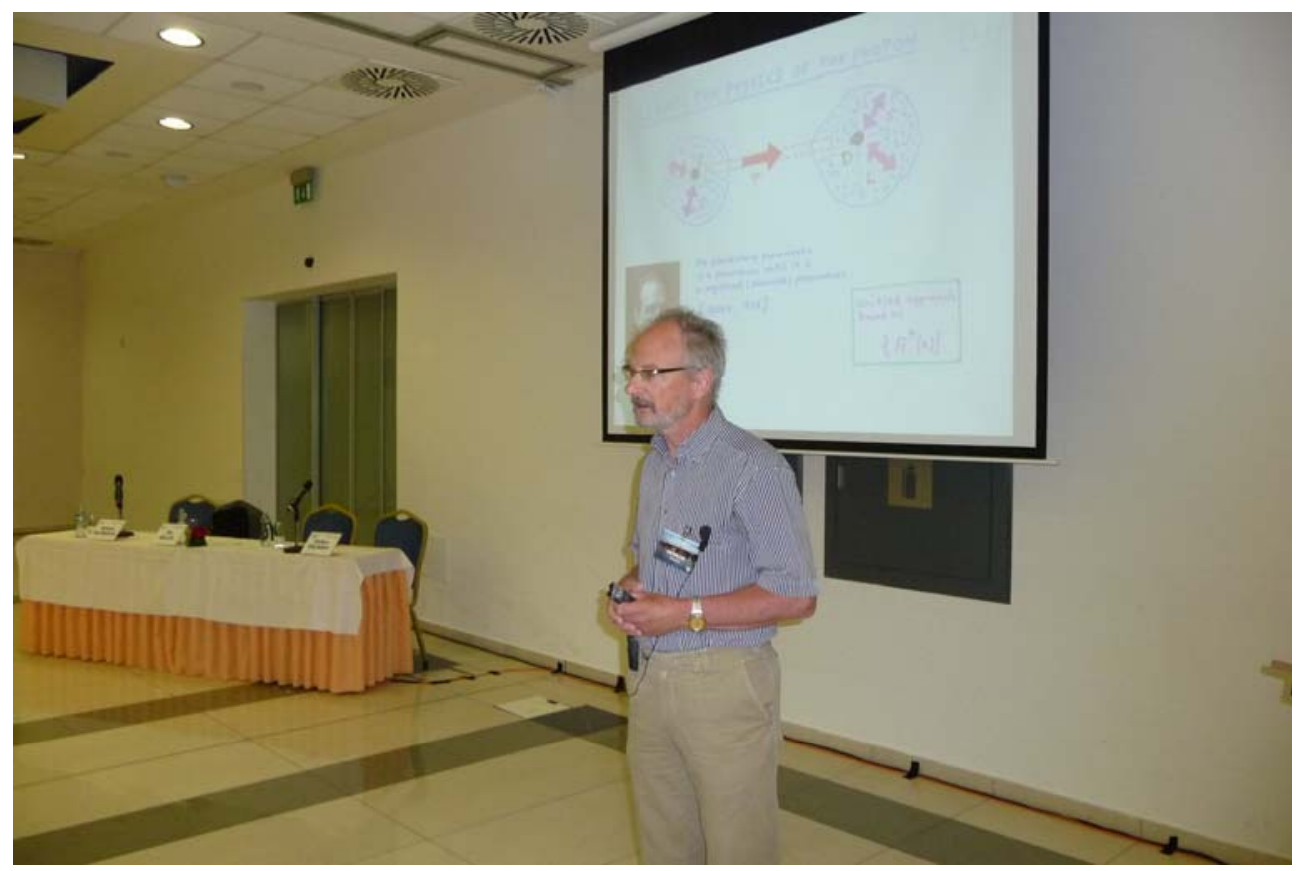

Ole Keller (Aalborg University, Denmark) explains what happens if we really want to understand the physics of photons in photonic systems and devices.

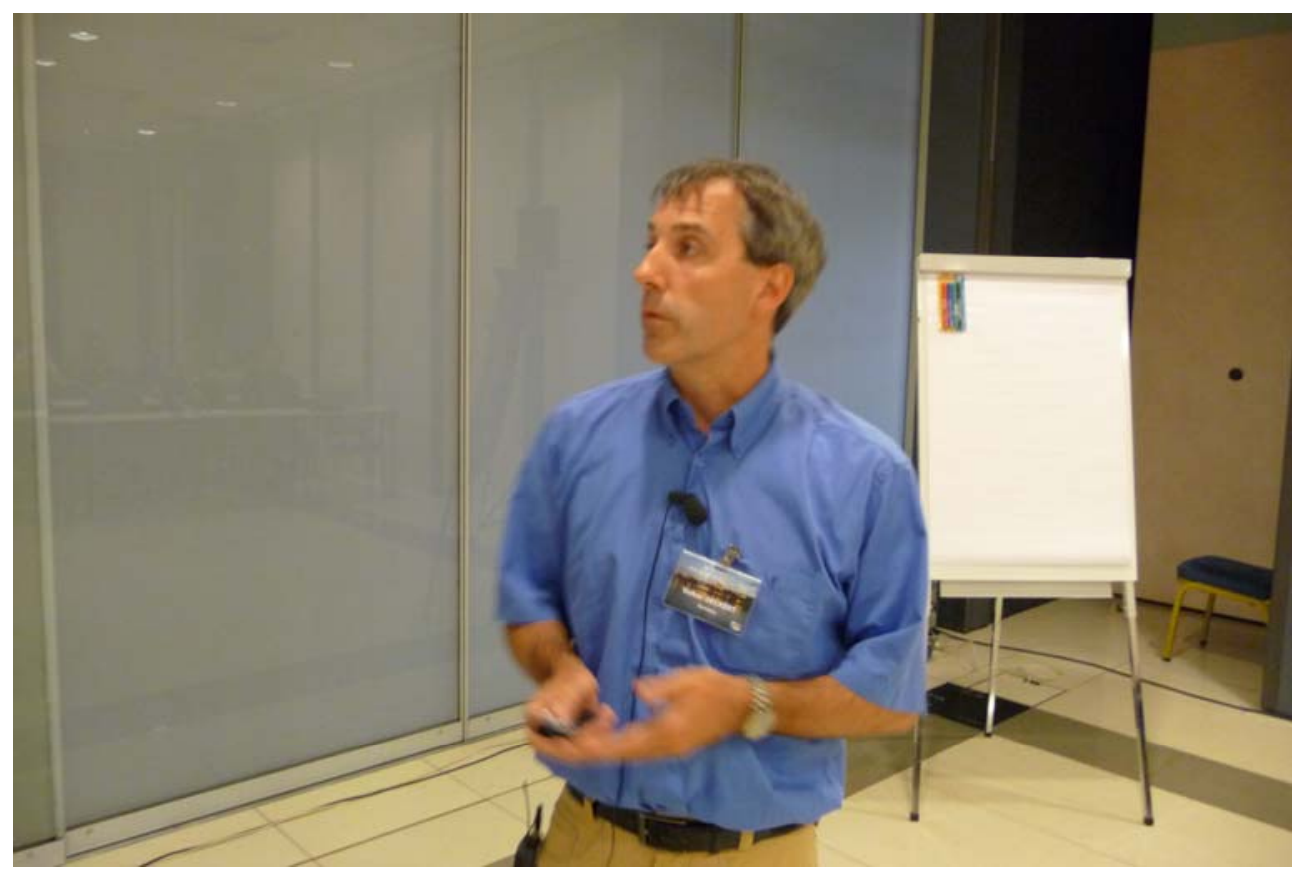

Volker Deckert (Friedrich Schiller University, Jena, Germany) shows how interesting "Biophotonics beyond the diffraction limit" $\square$. 


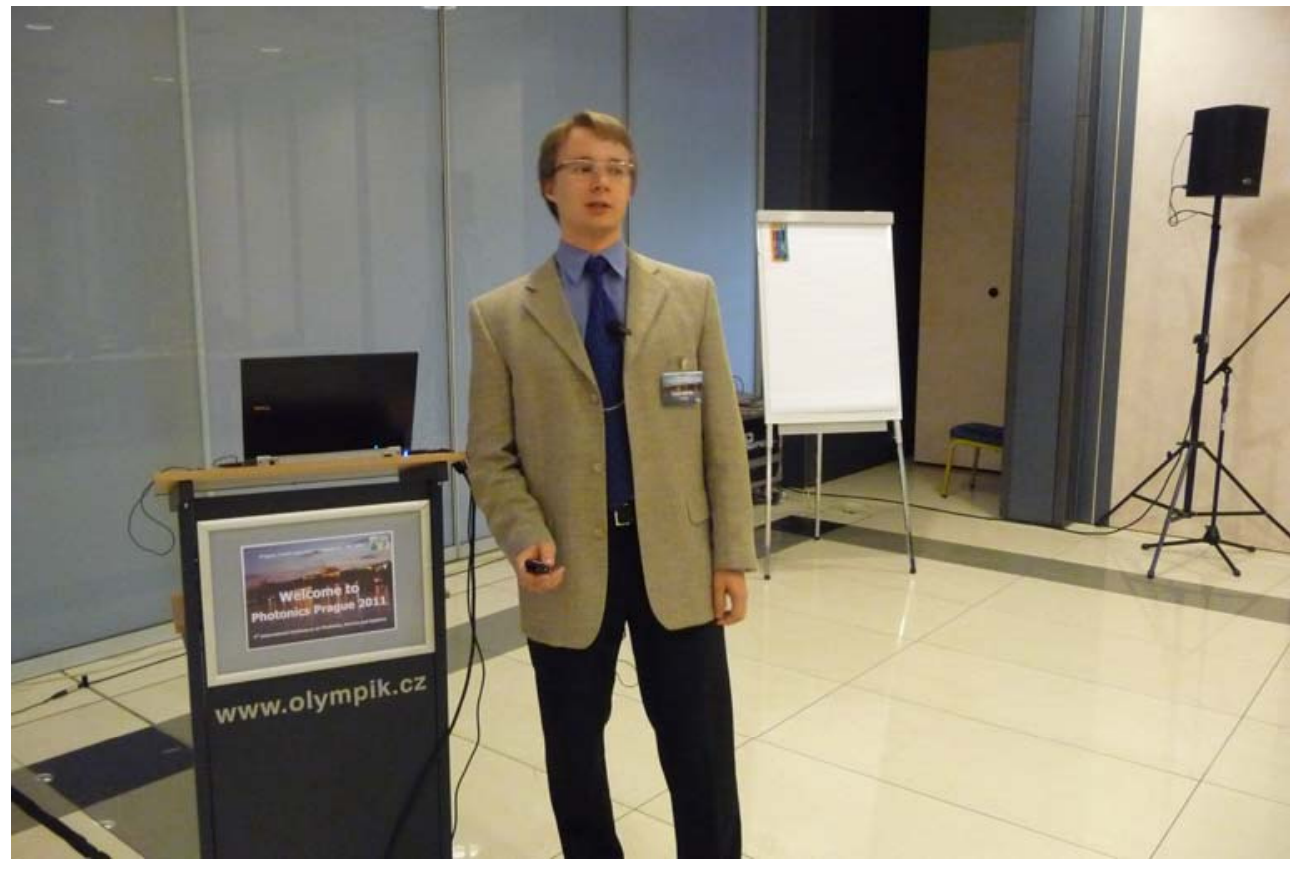

Timo Voipio (Aalto University, Finland) presents his SPIE Best Student paper.

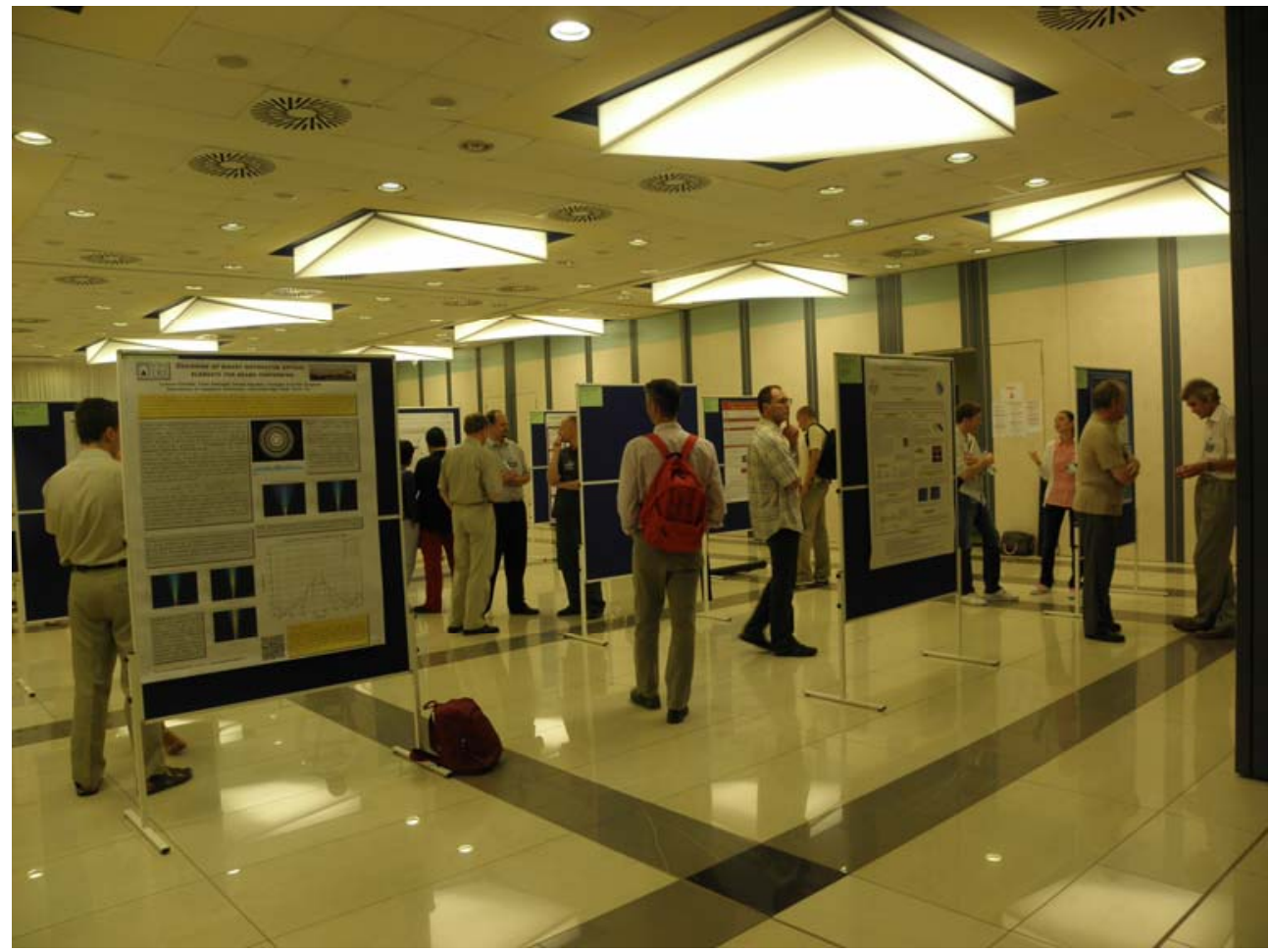

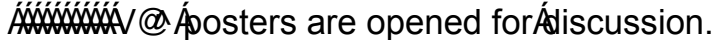




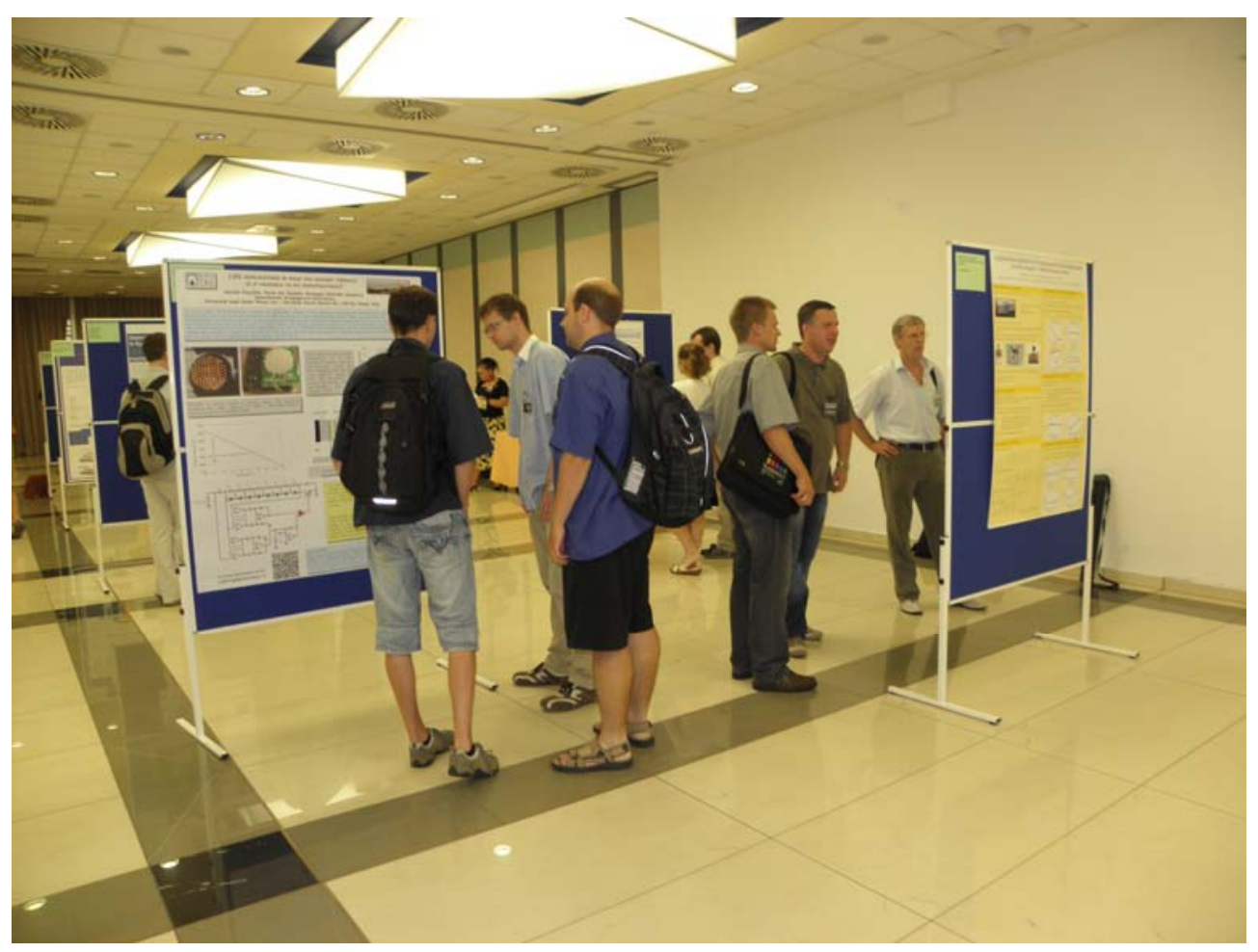

Poster session.

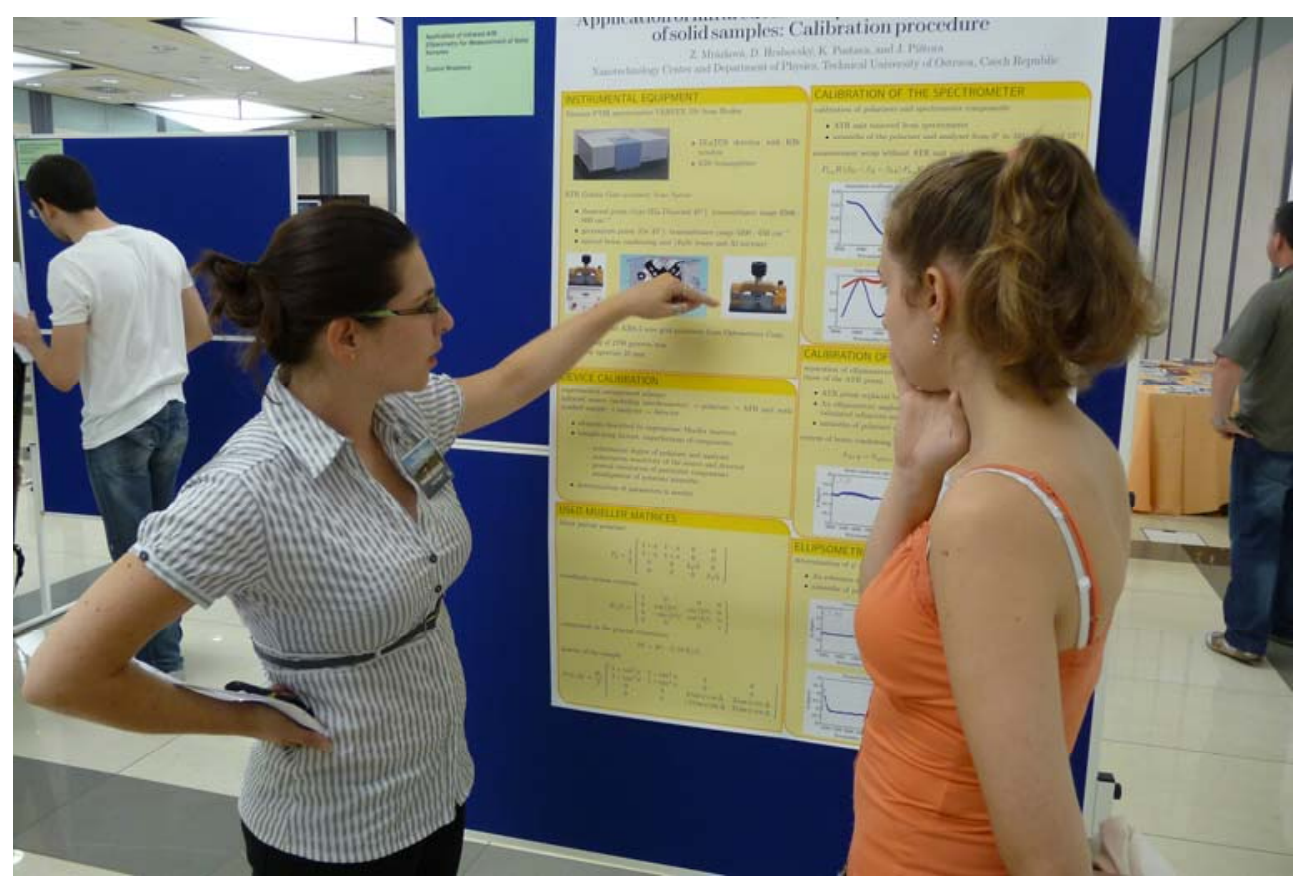

A discussion continues - Zuzana Mrázková (Czech Republic). 


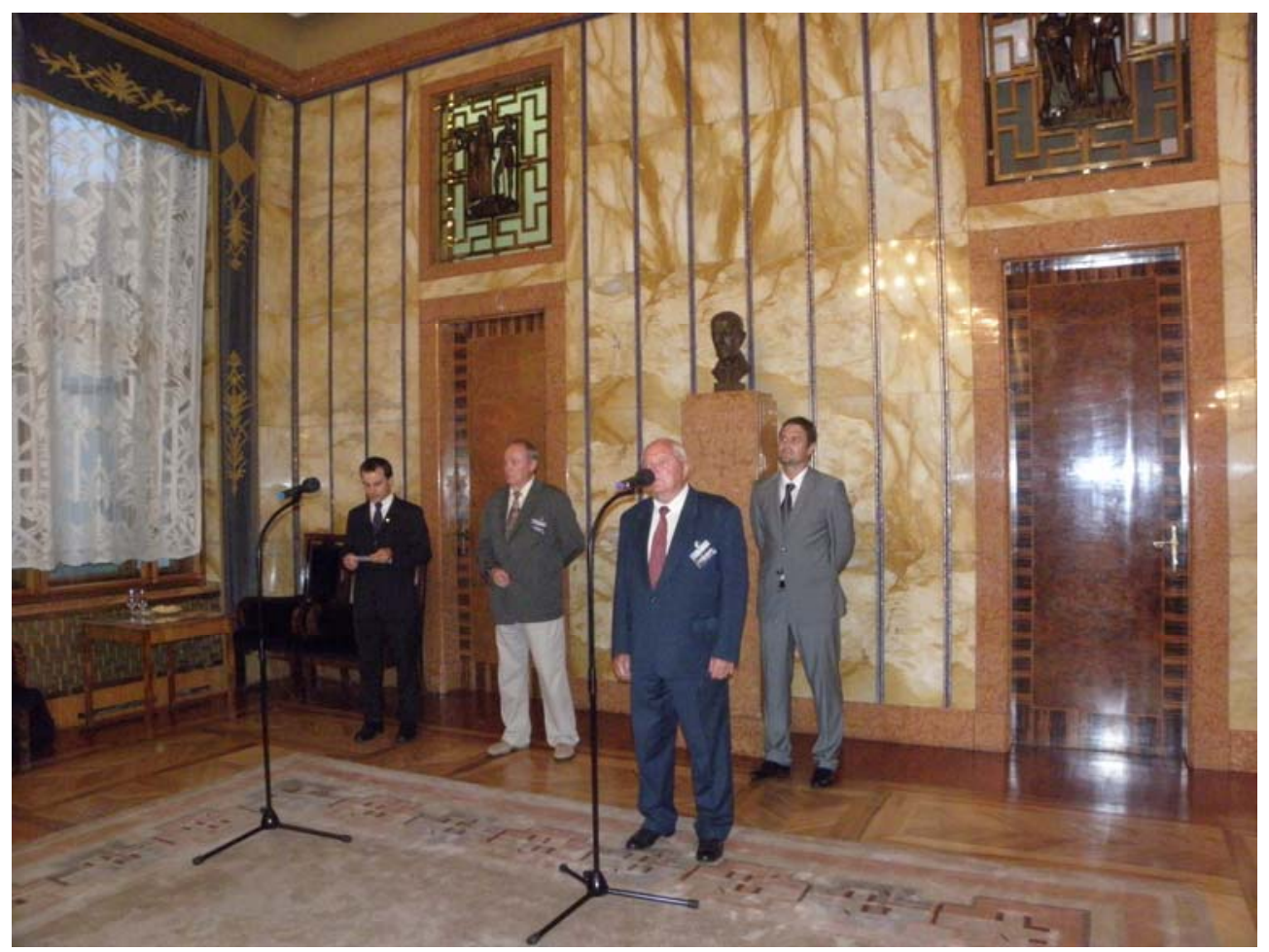

Conference Zelcome banquet (Wednesday August 24, 2011) in (esidence of Mayor of Prague.

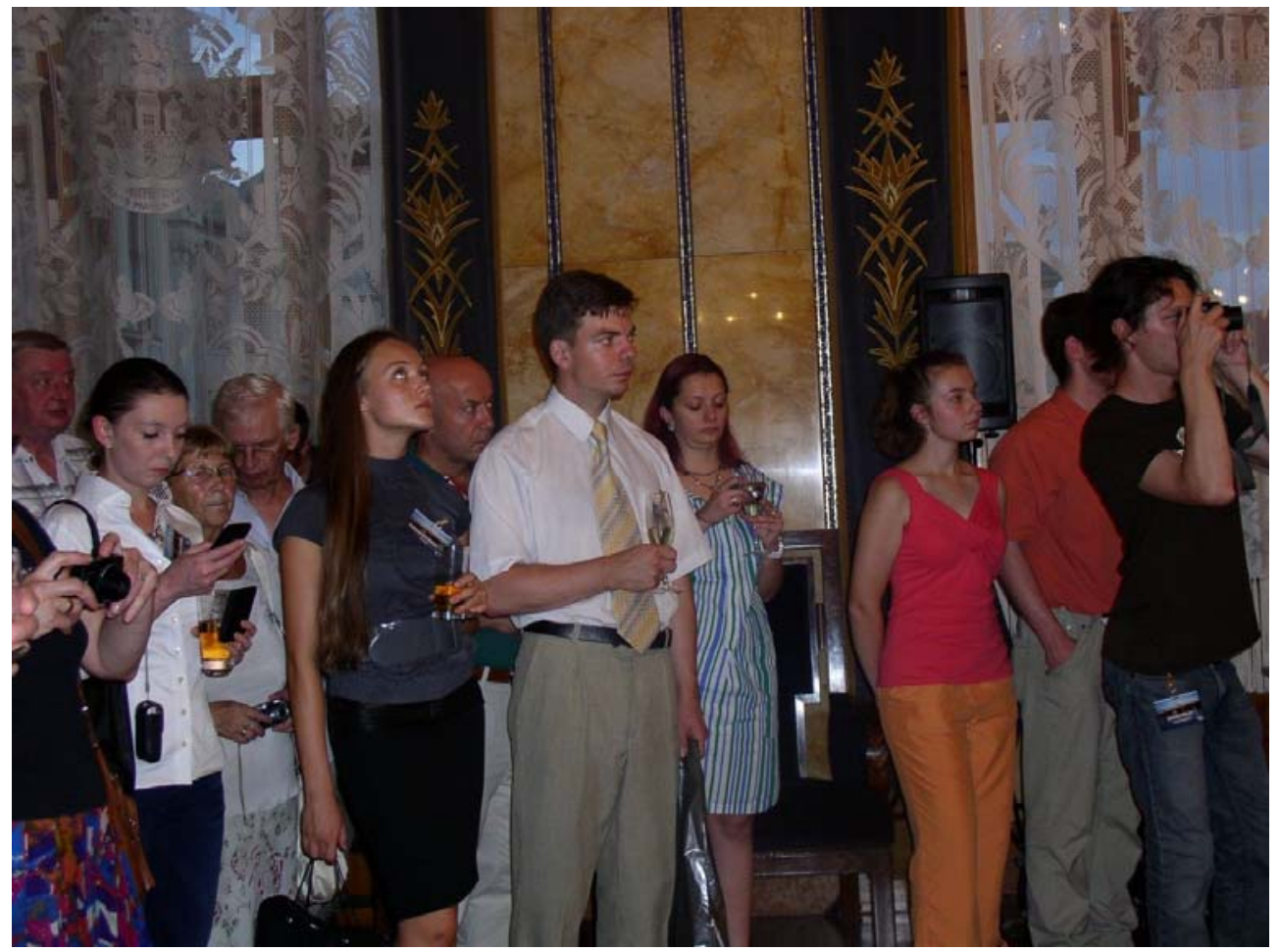

The participants contemplate the beauty of the Banquet Hall. 


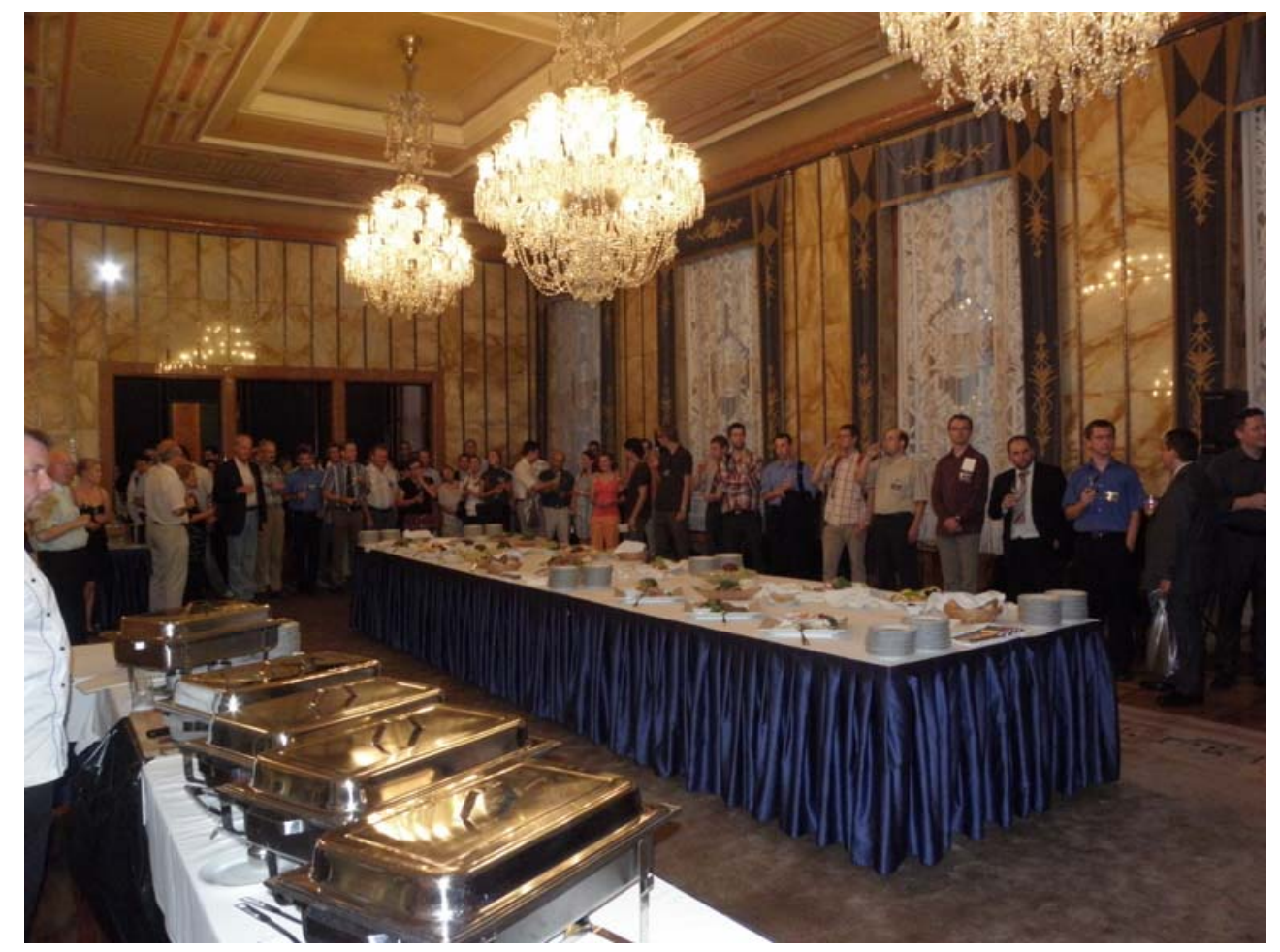

\section{Delicious food}

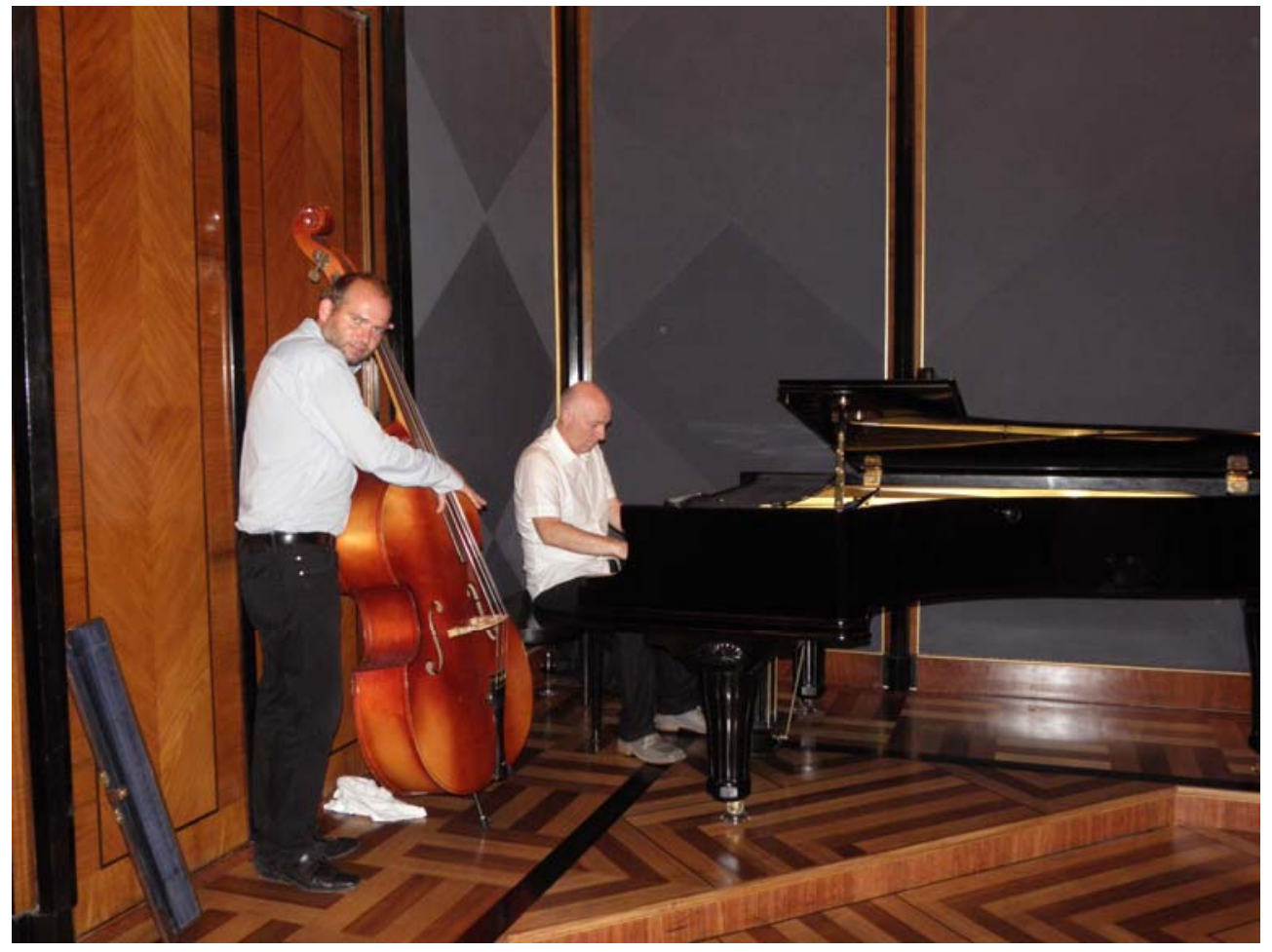

and music was here. 


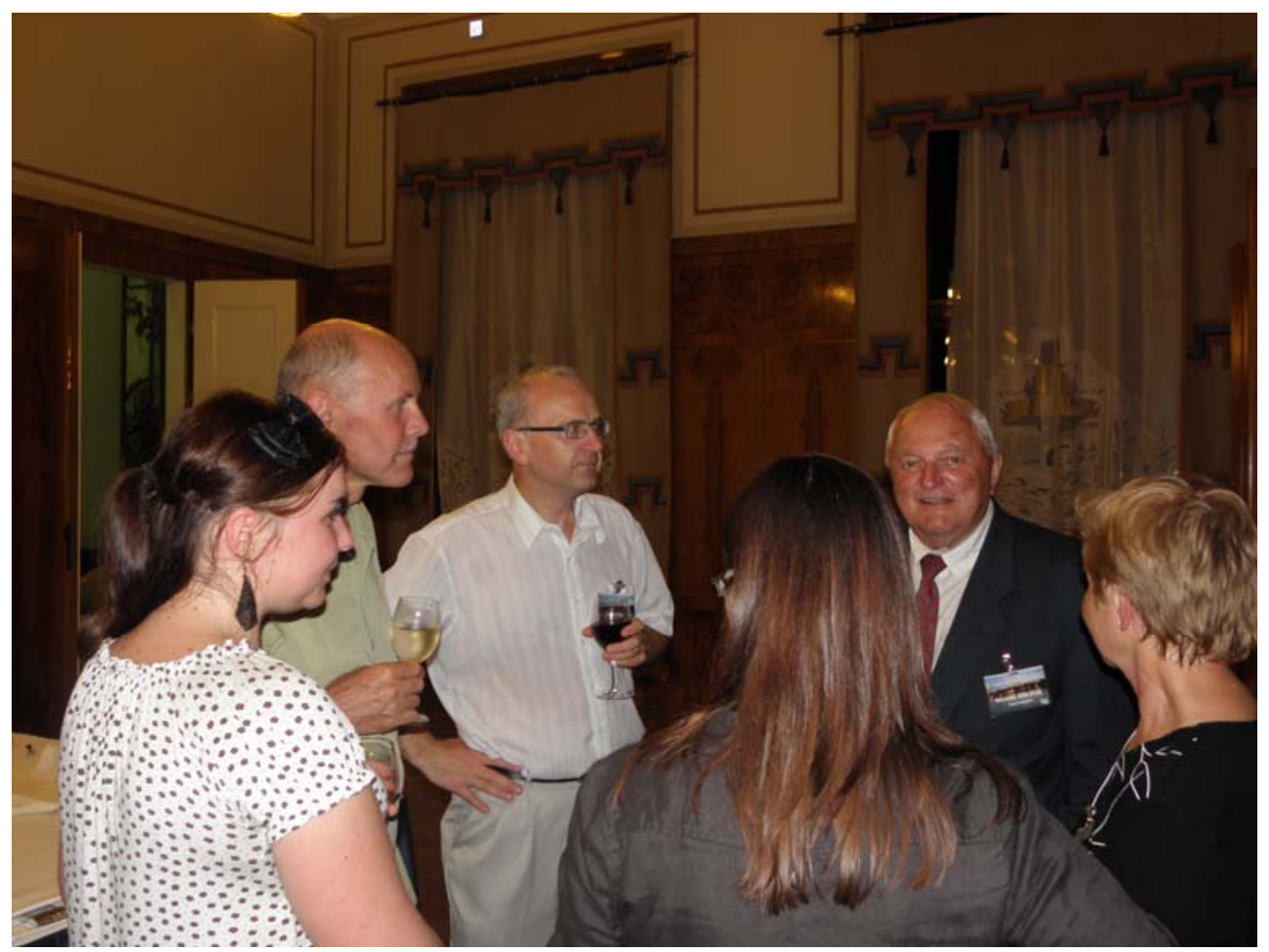

The participants were very satisfied not only with the banquet,

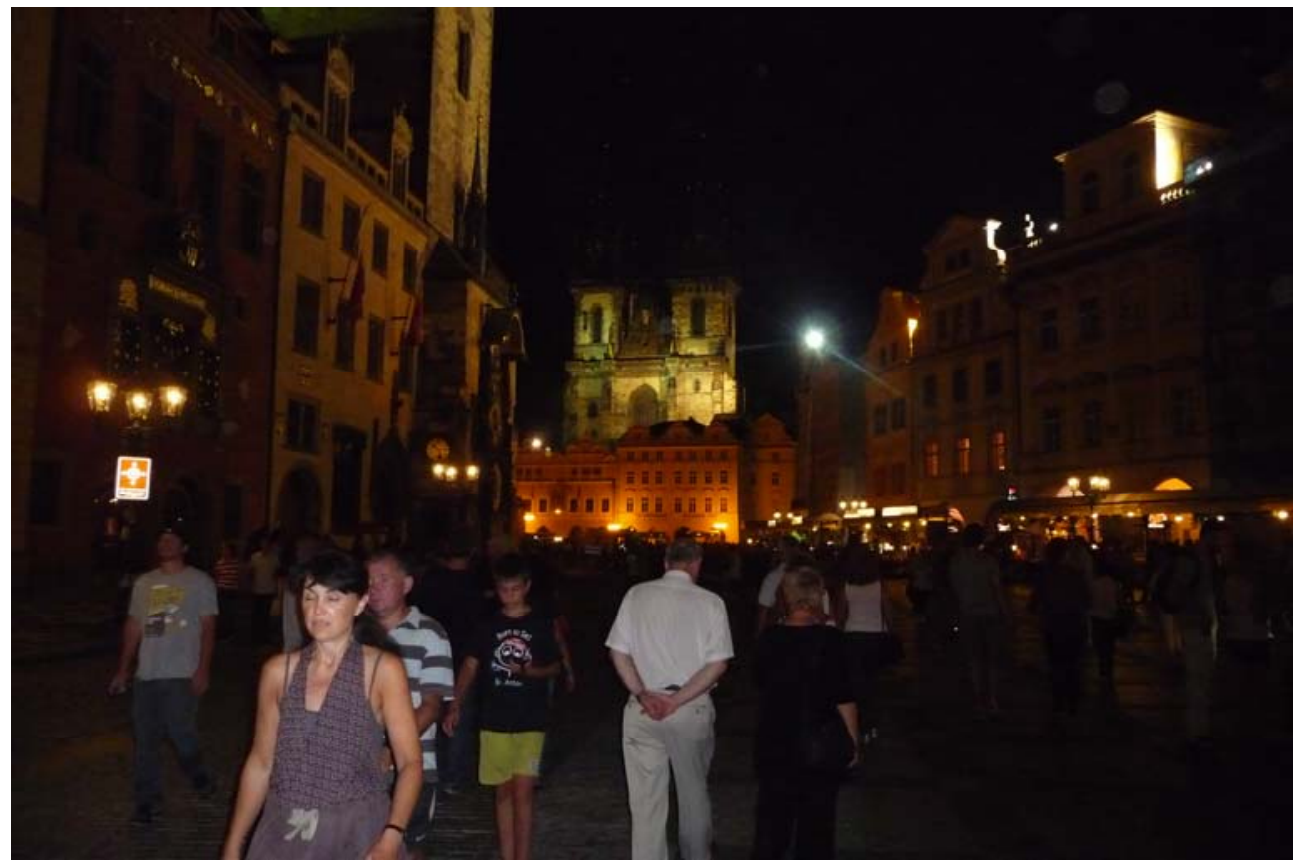

but also with a tour of Prague by night during a hot evening. 


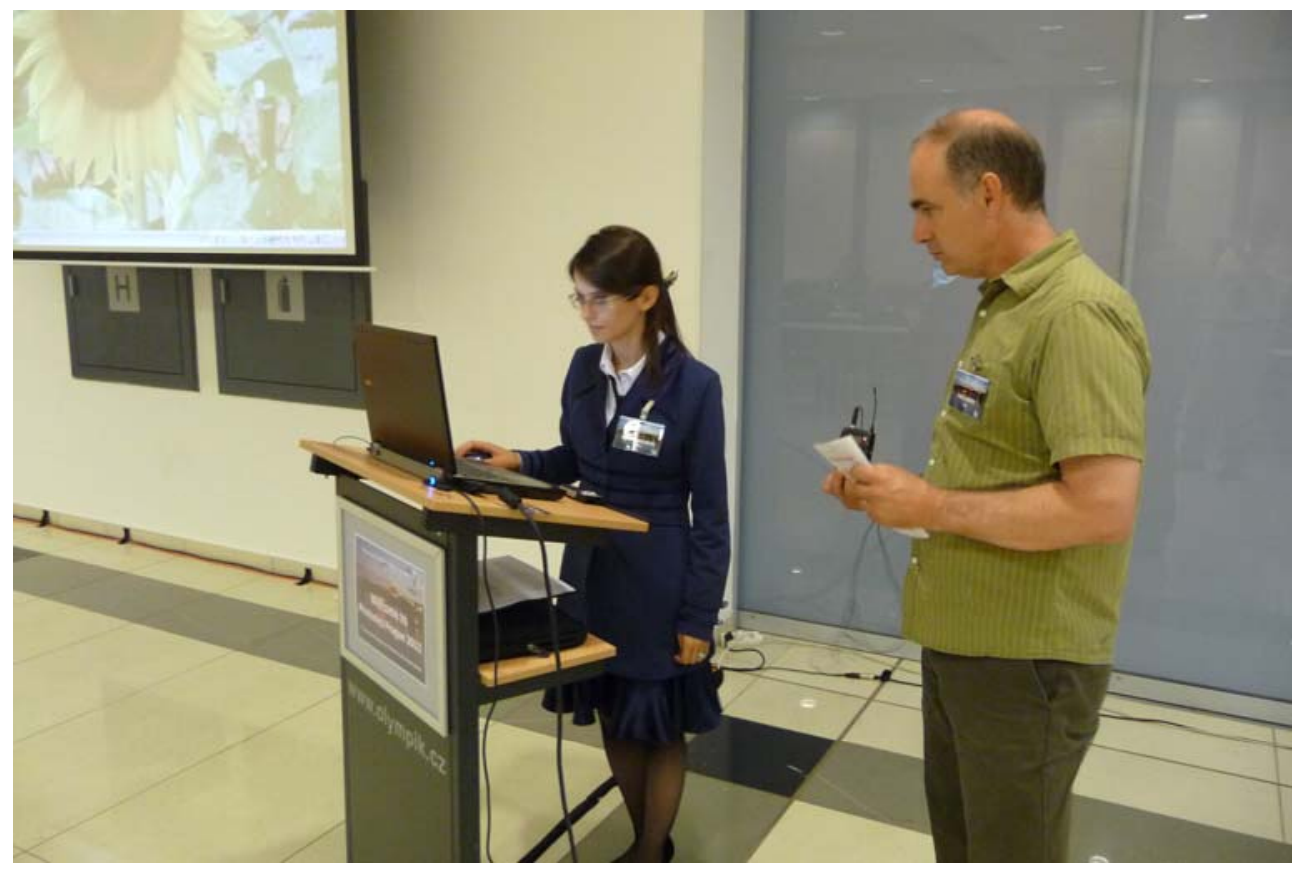

Dinara Dallaeva (Russia) looks for the presentation, and session chair Steve Smith (USA) supervises her talk.

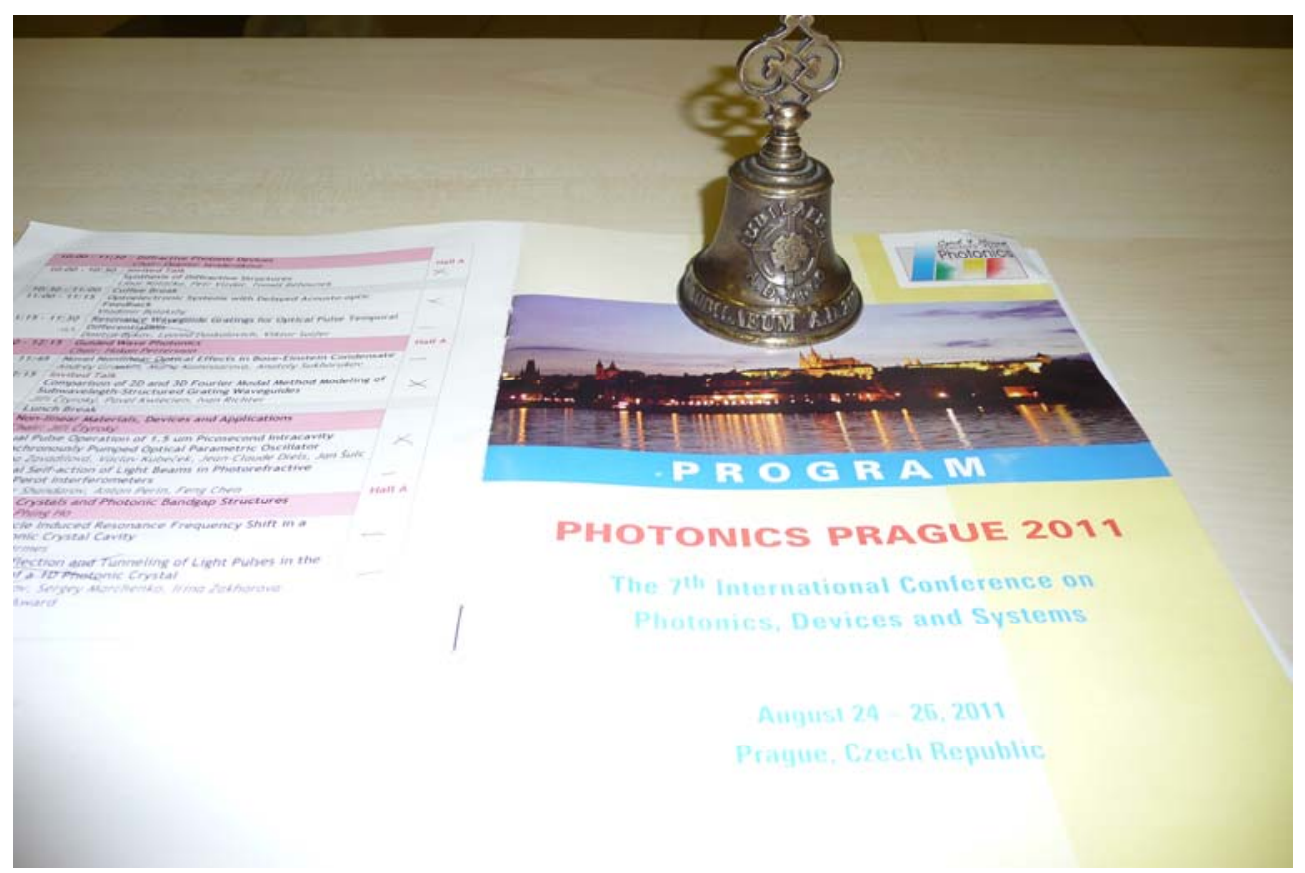

The Conference Technical program is almost over, and the conference bell is relaxing before the awards ceremony procedure. 
Downloaded From: https://www.spiedigitallibrary.org/conference-proceedings-of-spie on 26 Apr 2023

Terms of Use: https://www.spiedigitallibrary.org/terms-of-use 


\section{SPIE Best Student Presentation Award Photonics Prague 2011}

This year the conference honoured four laureates with SPIE Best Student Presentation Awards.

22 students took part in the competition. The evaluation commission chose four papers, three oral presentations and one poster presentation.

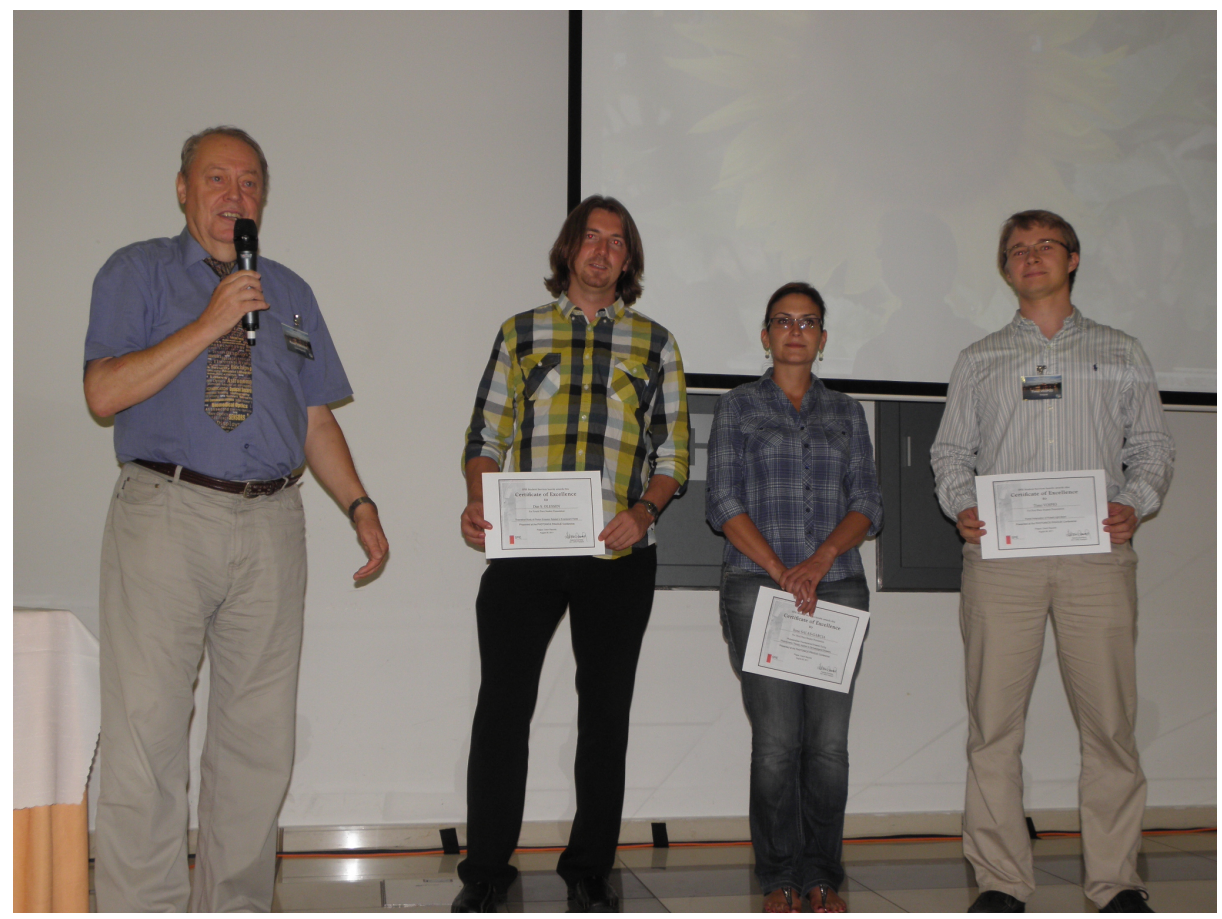

Podium of SPIE Best Student Presentation Award:

Pavel Tománek - conference chair, announcing the results.

From the left to right: Dann S. Olesen (Aalborg University, Denmark) - $4^{\text {th }}$ place for his presentation, Theoretical near-field studies of photon emission related to evanescent modes from quantum wells.

Irene Salas-Garcia (University of Cantabia, Santander, Spain) - $3^{\text {rd }}$ place for her presentation, Photosensitizer fluorescence emission during photodynamic therapy applied to dermatological diseases.

Timo Voipio (Aalto University, Finland) $-1^{\text {st }}$ place for his presentation, Partial polarization of pulsed light beams.

Not pictured: Zdeněk Pilát (Institute of Scientific Instruments, Czech Academy of Sciences, Brno) $-2^{\text {nd }}$ place for his presentation, Optical micromanipulations and Raman spectroscopy in microfluidic systems for live-cell analysis and sorting. 
Downloaded From: https://www.spiedigitallibrary.org/conference-proceedings-of-spie on 26 Apr 2023

Terms of Use: https://www.spiedigitallibrary.org/terms-of-use 


\section{CSSF Young Scientist Prize 2011}

The Czech and Slovak Society for Photonics (CSSF) awarded its prize for best presentation of young Czech and Slovak scientists at the Photonics Prague 2011 conference.

This time there were two coequal prizes:

Oto Brzobohatý, Institute of Scientific Instruments, Academy of Sciences, Brno, for his presentation, Advanced optical manipulation with tailored counter-propagating laser beams, and Markéta Zezulová, Faculty of Biomedical Engineering, Czech Technical University in Prague, for her presentation, Study of thin films of $\mathrm{LiNbO}_{3}$ using FTIR and Raman spectroscopy.

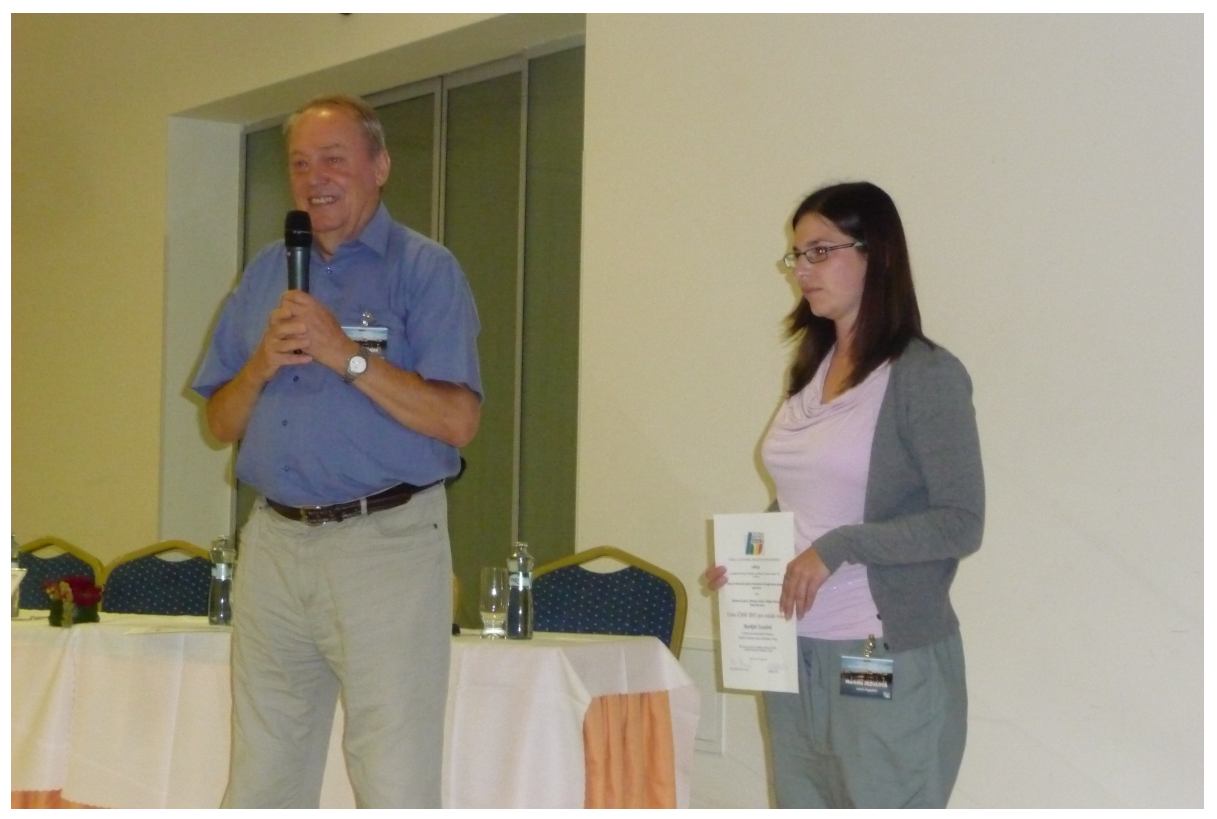

Markéta Zezulová receives her diploma. 
Downloaded From: https://www.spiedigitallibrary.org/conference-proceedings-of-spie on 26 Apr 2023

Terms of Use: https://www.spiedigitallibrary.org/terms-of-use 


\section{Conference Supporters}

We wish to thank following organizations for their contribution to the success of the conference.

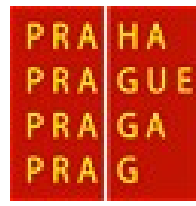

Photonics Prague 2011 was organized under the auspice of the 1st Deputy Mayor of the City of Prague, Karel Březina.

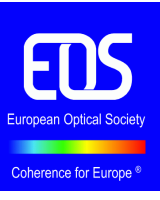

European Optical Society

Cooperating Organizations:
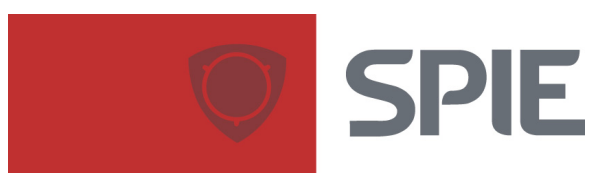

Local Organizers:

- $\quad$ CSSF-Czech and Slovak Society for Photonics

- Action M Agency 
Downloaded From: https://www.spiedigitallibrary.org/conference-proceedings-of-spie on 26 Apr 2023

Terms of Use: https://www.spiedigitallibrary.org/terms-of-use 